\title{
The Politicians' Buddhist Morality on Students' Opinions at Mahamakut Buddhist University: Lanna Campus, Chiang Mai, Thailand
}

\author{
Phramaha Wiset Sorphobdee ${ }^{1}$, Thammarat Photisuwanpanya ${ }^{2}$, Somyot Panyamak ${ }^{3}$, Worayuth \\ Sathapanasuphakul ${ }^{4}$, Mongkonchai Somsri ${ }^{5}$ \\ ${ }^{1}$ Mahamakut Buddhist University Lanna Campus, ${ }^{2}$ Rajabhat Chaiyaphum University, ${ }^{3}$ Department of Political Science \\ Mahachulalongkornrajavidyalaya University Phayao Campus, ${ }^{4,5}$ Mahamakut Buddhist University Lanna Campus \\ ${ }^{1}$ veesaad@hotmail.com, ${ }^{2}$ tumarat.39@gmail.com, ${ }^{3}$ somyot.pan@mcu.ac.th, ${ }^{4}$ Worayuth16@gmail.com, \\ ${ }^{5}$ Mongkolchai1218@gmail com
}

\begin{abstract}
The objectives of this research were: 1) to study the students' opinions on Politicians' Buddhist morality; 2) to analyze personal factors affecting students' opinions on politicians' Buddhist morality; and 3) To study recommendations on politicians' Buddhist morality. The samples were 269 students at Mahamakut Buddhist University: Lanna campus, Chiang Mai, Thailand to whom questionnaires were distributed for collecting of data which were analyzed through frequency, percentage, mean, standard deviation, and $\cdot 2$-test by setting the statistical significance at 0.05 . The research Results were found that: 1) The overall level of Buddhist morality of Thai politicians as perceived by students in all three aspects was low with a mean of 2.12 and a standard deviation of 1.216. The aspect with highest mean was the principles of building the righteousness, followed by the principles of building the unity, and the principles of building the solutions of conflicts. 2) The test of hypothesis revealed that the gender does not affect the students' opinions towards politicians' Buddhist morality, which does not meet the defined hypothesis, while the age and educational year affect the students' opinions towards politicians' Buddhist morality, which meets the defined hypothesis at 0.05 , and 3) The students provided their recommendations on the political problems of Thai politicians in terms of the Buddhist morality that "Politicians always think of oneself, self-centered, do not listen to the opinions of others, one's own ideas are dominant, different ideas and other aspects cause disturbance and dissatisfaction of money gained, political conflicts, and divided groups of citizens". In addition, they provided their recommendations on the development of Buddhist morality for politicians that "Listen to each other, reliance on rightness rather than pleasure, adhesion to the teachings as main practices and way of life, recognition of causes and effects, do not listen to only one side, leaders should follow Buddhist concepts, no selflessness or hurting to others, politicians should have the precepts, meditation and wisdom, should more concentrate during talking, building of love to the family, and teaching of children for the future of nation".
\end{abstract}

Keywords

Politician, Politicians' Buddhist morality, Mahamakut Buddhist University

Article Received: 10 August 2020, Revised: 25 October 2020, Accepted: 18 November 2020

\section{Introduction}

Human society arises from the coexistence and performance of activities together so that humanity can survive and maintain their race. Defining the rules and regulations must fall under the principle of fair allotment. This principle only applies to the cases of sharing benefits, beneficial burdens and common obligations to all members of the society, whether these benefits, burdens and obligations are those already present or those as the result of the joint action of the society. We may call these benefits and burdens as social benefits and burdens. Since they are benefits and burdens occurring to all members of the society, the sharing of benefits and burdens must adhere to the principle of equality. Therefore, there is an initial claim that in determining the regulatory systems in the society, all members of the society must be equally involved in these benefits and burdens, unless there is any widely accepted reason that any specific case may be able to share the benefits and burdens unequally. This refers to the principle of social equality.

Politicians are always known and should exactly act as a good example to the people in the society. They should create and conduct behaviors that deserve praise, act as a good model for the people in the society, not overly influence the materialism, and focus on the development of morality and ethics (Jintana Chaichompu, 2011). Once the human has the passion and material greed over their mind, the meaning of politics has been changed to the struggle against each other for their own interest. Recently, it has been indicated that men are under the power of materialism and the politics has become incorrect and non-ideal (Somsak Niumlek, 2001). Politicians must not conduct dissipated behaviors. The standards of conduct that are generally accepted include not being a liar, sincerity and responsibility both in their own words and actions (Pinida Prayurasiri, 2008). Current Thai politicians lack in core political ethics, including voting fraud, buying - selling of voting rights, discredit, conflict of interest, and use of dirty canvass (Phanomsit Sonprajak, 2009). This is consistent with the research of Teerapat Serirangsan (2005) who found the ethical problems and conflict of interest among politicians, such as fraud in the election, buying and selling of voting rights, and exercise of political authorities for their own benefits. Political ethics and conflict of interest of current politicians are much worse. The opposition tries to present the defects and corruption of the government, while the government tries to clarify the allegations and present their work. This may be said that the politicians always hide their own evil while seeking to destroy the opposition. As a result, we can see that the lack of political ethics with latent conflict of interest, the sake of followers, and the corruption and abuse of power under the political patronage system will still remain in Thailand within the Thai democratic society. 
Recently, Thailand has been faced with the lack of ethics of the ruling-class people, i.e. governmental servants, both regular officials and politicians. Professional ethics have therefore been defined which state explicitly that what can and cannot do with the increased penalties for obvious violations of the ethics in the form of civil and criminal offenses. In some societies, the code of ethics has been established by specifying what should and should not do without penalties. In this case, there may be only a committee to consider any case of ethical violations conducted by people in such societies. For regular officials, there are only a few serious ethical violations because there is a framework of discipline to control the behavior and an administrative penalty by moving out of positions with misconduct.

Another crisis, which is particularly worrisome, is a willful violation of the laws and moralities among disobedient government officials and executives, including the abduction and killing, destruction of witness and evidence in the cases, extrajudicial killing without any reason claimed under the law, torture of suspects, incorrect charge for innocent people, and creation of false witness and evidence. This crisis is even more severe than the corruption and has become common in Thailand. As we all know, this bad thing has happened because Thailand's current social values tend to accept everything, whether bad or good. It is a society where everyone can do everything as he or she likes, or "A Permissive Society". This crisis has caused troubles and difficulties in every area within our country so Thailand has been faced with chronic problems and cannot be a good society as sustainable as desired.

The crises in developing countries, including Thailand, are mostly caused by corruption and misuse of power among the chief executives of the country, both regular officials and politicians. As a result, the development of these countries cannot proceed to the goals of national interest, i.e. stability, prosperity and dignity in the international political arena. In addition, there has been a gap between the ruling-class people and the ordinary people. Political, economic and social problems have therefore been occurring continuously. The 1997 Constitution of the Kingdom of Thailand provides measures to resolve such problems by setting up independent bodies and ethical systems to monitor and control the behavior and conduct of regular officials and politicians. However, the implementation of these measures has not been explicitly successful, especially politicians who are volunteering to serve the public as a member of the parliament. Previously, politicians were controlled by defining the code of ethics under the responsibility of the ethical committee of the parliament, but the conduct of politicians could not still be controlled. Therefore, the system for controlling the ethics of politicians must be developed. In Thailand, there are three aspects of moral and ethical problems in the political community, i.e. corruption, misuse of power, and sake of themselves and their followers without taking into account the social and national benefits. These problems can be solved by defining the rules, code of conduct, and development practices covering all three aspects.

Many sectors involved have agreed by proposing the development of political parties so that political parties are key institutions to socialize the people and strengthen the political culture sustainably conducive to the democracy. These institutions also can create and control the ethics of politicians effectively. This is an issue that should study the roles and duties of political parties in the future to respond to the democratic development of the country, and in particular to develop and maintain the morals and ethics of politicians. Political participation is part of promoting the rights and power of citizens, both individuals and communities, to develop the ability to manage for the benefits of the groups and control the use and distribution of community resources. This will cause the processes and structures that rural people can express their abilities and benefit from this development. In addition, the political participation changes from the development mechanism of the state to those of the public by decentralizing the planning power from the center to the regions in order to make the regions independent with political, administrative and bargaining power in resource management, which is subject to the same standards and can be verified. The public hearing is the expression of the public to watch, monitor and control the performance of their representatives. In the event that the legislature or executives are prepared to enact any laws or establish any policies or measures which can affect the lives, rights and freedom of the people, as an owner of the sovereignty, the people can claim to clarify the facts and pros and cons before issuing or enforcing such laws, policies or measures. In addition, a referendum can be involved with the people, in particular those relating to the important policies or laws that have a clear impact towards the rights, freedom and well-being of the people, such as acceptance of the draft constitution, tax increment, and construction of a dam or power plant. As an owner of the sovereignty, the people can request the state to conduct a referendum before enacting any important laws or performing any important actions in order to inquire the opinions of most people which will be the last decision.

Previously, for the politicians, another group of people in the society, there were no clearly established professional groups and ethics until the 1997 Constitution of the Kingdom of Thailand which provides the ethics of politicians in Section 191 for the first time. It provides that the House of Representatives and the senate have the power to enact regulations on the conduct of the parliament meeting as well as the power to enact the code of ethics of the members of Parliament and Commission. On Tuesday, May 22, 2014, a group of persons calling themselves "National Council for Peace and Order (NCPO)" seized the government power and abolished the 2007 Constitution of the Kingdom of Thailand. One of their reasons was that the most people doubted the government with extensive dishonesty and misconduct and independent agencies were dominated by politics. This implies that the measures to supervise the morals and ethics of Thai politicians were unsuccessful according to the intent of the Constitution. These existing measures should therefore be reviewed and considered from related documents to determine an academic framework that is expected to tackle the lack of ethics of politicians.

Moreover, the election process in Thailand provides the money a chance as a factor determining the outcome of the election which can cause complex problems. Election process has thus become a process of using the technique for converting money to a vote, rather than a process of political participation of the people themselves to recruit the political 
personnel as their representatives into the political system. Activities of political parties have become a political investment and business that seek for profits. Later, a system of political recruiters has been established to convert the money of capital groups into political interest. Political parties should establish a two-way communication for the exchange and receiving of information between the parties and the public, which can cause the complex relationship between the parties and the public. While the public can express and request any demand via the media, the political parties are able to recognize and timely and relevantly interact with diverse groups as well as to distribute more efficiently. Therefore, it is required to bring religious principles, especially Buddhism, to help in this subject because religious principles or systems can create good people. When good people go in any system, such political system will be good as well. A political science system is a system of physical government, while Buddhist principles are a system of mental government. Political science and religion must proceed simultaneously and either cannot disappear (Phramaha Tammarat Ariyatammo, 1999). The ethics of politicians are involved in the administration, government and operation of the nation as a political goal to administrate the state peacefully. Politicians should consider their real targets by administrating the state peacefully and establishing the public welfare conducive to the goal of all lives and the social goals. Currently, there are many political conflicts, including the revision of the Constitution, roles and duties of the Constitutional Court, red-shirt, yellow-shirt and colorful shirt people, soldiers, businesses, especially members of representatives and elected and appointed senators. These are caused by political conflicts with various groups and ideologists. Although there is a wide range of ethical rules and regulations for politicians, there is no unity. There is still chaos both inside and outside the parliament by the protesters.

According to the Buddhist concepts, political conflicts can be solved based on various Buddhist morality that politicians should put into practice as said by Phrathampitaka (P.O. Payutto) (1999: 210-211). He stated that the ethical standards of politicians include the duties, personal behavior and public welfare principles of a great ruler, including basic morals for everyone, such as five precepts, abstinence from vices, and honesty. Important Buddhist morality to promote the political peace and affect the public well-being in the era of democracy development includes the principles of solving the conflicts, fostering the unity, and enhancing the righteousness. In addition, there are other principles of promoting the well-being, such as principles of connecting the society, being a perfect person who is regarded as a good and valuable member of the nation, being a moral person, being a good member who helps create the good society, and being a person who can rely on and take responsibility for their own.

The Buddhist morality was deployed in the past as seen in the world history. Ashoka the Great introduced the political science policy by adhering to the principles of winning the hearts of the people based on the fair administration, consideration of public happiness, promotion of public utilities, social welfare, and extensive maintenance of arts and cultures. This made the India subcontinent in his reign a major source of civilization that was extensive and stable. His name has been more prolonged and called with respect and esteem by the posterity than other superiors who conquered many territories by wars.His routines became traditions and practices generally followed by many kings who adhered to the pacifism and who were named the Great, such as Phrachao Kanisok the Great (78 - 101), Phrachao Hatsawattana $(606$ - 648), Phrachao Tammaban of the Idea subcontinent $(780-830)$, Phrachao Chaiworaman $7^{\text {th }}(1181$ 1218) of the ancient Khmer empire, and King Ramkhamhaeng the Great (1277 - 1317) of the Kingdom of Thailand.

The behaviors of Thai politicians as seen in the media have not followed the principles of Buddhism. There are corruptions in many projects, road constructions, forest invasion, flooding problem-solving, political floating, including behaviors of politicians in the parliament by speaking abusive words, sleeping in the meeting, absenting the meeting and foolishly playing a role of the members of the parliament as the joking council in a TV program. These are not in accordance with the ethical standards of political officials. Clause 10 provides that political officials shall conduct themselves in an ethical and moral framework, both personally and publicly, and act themselves for the faith and credibility of the people. In addition, the above-mentioned behaviors of politicians have clearly caused the political conflicts, which as a result make the public has been disgusted at the behaviors of politicians. This university is located in the political settlement of Pheu Thai Party and is a specialized educational institute that emphasizes the academic excellence based on the Buddhism concepts. Since the vision of this university says that "Serves as the center of Buddhist wisdom of the world that can lead and end the conflicts in the society based on the Buddhist principles", the author therefore studied the opinions of students in this university towards the behaviors of Thai politicians according to the principles of Buddhist morality, enhancement for solving problems of conflicts, unity, and political legitimacy.

\section{Research Objectives}

1. To study the students' opinions on Politicians' Buddhist morality.

2. To analyze personal factors affecting students' opinions on politicians' Buddhist morality.

3. To study recommendations on politicians' Buddhist morality.

\section{Research framework}

1. Content : there are three Dhammas in the content as Buddhism morality Saraniya-dhamma : Buddhist morality for the solution of conflict, Aparihaniya-dhamma : Buddhist morality for the enhancement of unity, and Raja-dhamma : Buddhist morality for the Buddhist morality for the enhancement of unity of political righteousness

2. Area : Mahamakut Buddhist University; Lanna Campus ; Chiang Mai, Thailand.

3. Population : Politicians' Buddhist morality in students attitudes in Bachelor degree students of Political Science Programs at Mahamakut Buddhist University; Lanna 
Campus ; Chiang Mai, Thailand, ware for a total of 824 students

\section{Research Methodology}

\section{Population and Sampling}

1.1 The population of this research were the students of Mahamakut Buddhist university : Lanna campus ; Chiang Mai, Thailand, for a total of 824 .

1.2 The sampling of this research were the students of Mahamakut Buddhist university : Lanna campus ; Chiang Mai, Thailand, for a total of 269 prom 824.

\section{Technique and way of random sampling}

This research were to study "The Politicians' Buddhist Morality on Students' opinions" that were the samplings and obtaining samplings by stratified of Er of Taro Yamane.

$$
\mathrm{n}=\frac{\mathbb{N}}{1+N e^{2}}
$$

$\mathrm{N}=$ the total of population were 824

$\mathrm{n}=$ The total of sampling

$\mathrm{e}=$ the standard of deviation from sampling were $95 \%$ or 0.5

$$
\begin{aligned}
& n=\frac{824}{1+\left(824 \times 0.05^{2}\right)} \\
& n=269
\end{aligned}
$$

\section{The research instruments}

This research has questionnaires were designed to be 3 parts Part I . It was closed- ended question which concerned about the factors of genders, ages and classes year.

Part II . It was closed - ended question which concerned about the Politicians' Buddhist Ethics in Opinion of Students with 3 dhammas :

Saraniya dhamma : Buddhist ethics for the solution of conflict. Aparihaya - dhamma : Buddhist ethics for the enhancement of unity

Raja - dhamma : Buddhist ethics for the enhancement of political righteousness.

For the questionnaires in part II, It was the summated rating scale of Rensis Likert, (1992) or Linkert - type scale which divided to 5 levels 5 - the highest , 4 - the high , 3 - medium , 2 - less , 1- lower

And we have the score average which could be identified in statistic number as

\begin{tabular}{c|c}
\hline The average scores & meaning \\
\hline $4.50-500$ & The highest ethics \\
$3.50-4.49$ & high ethics \\
$2.50-3.49$ & medium ethics \\
$1.50-2.49$ & less ethics \\
$1.00-1.49$ & low ethics \\
\hline
\end{tabular}

Part III. It was the open-ended questionnaires to suggest Thai Politicians' Buddhist Ethics

\section{Result of the data analysis}

After the researcher has got all the data from questionnaires, statistics for data analysis included Percentage, Frequency, Mean, standard deviation and $\chi^{2}$-test.

Part 1. Personal data of the person who answer the questionnaires.

Part II. The statistic for data is the personal data included Mean, standard deviation

Part III ; the hypothesis test is the personal data of students effective to the attitude of politicians Buddhism morality attitudes by $\chi^{2}$-test and has statistically significant difference was $\mathrm{p}=0.05$

Part IV. The result of the suggestion to the Politicians Buddhism morality were presented in descriptive tables

\section{Conceptual framework}

Researcher has set the conceptual framework, independent variable and dependent variable also analyze the personal factors which effect the students attitudes of Mahamakut Buddhist University, Lanna campus through the politicians at the present time with 3 ethics : Buddhism morality for the solution of conflict, Buddhism morality for the enhancement

\begin{tabular}{|c|c|}
\hline Independent & Dependent Variable \\
\hline $\begin{array}{l}\text { Personal } \\
\text { factors } \\
\text { - Gender } \\
\text { - Age } \\
\text { - Class year }\end{array}$ & $\begin{array}{l}\text { Politicians' Buddhist } \\
\text { morality in students' } \\
\text { opinion } \\
\text { - Buddhist morality for the } \\
\text { solution of conflict } \\
\text { - Buddhist morality for the } \\
\text { enhancement of unity } \\
\text { - Buddhist morality for the } \\
\text { enhancement of political } \\
\text { righteousness }\end{array}$ \\
\hline
\end{tabular}
of unity, and Buddhism morality for enhancement of political righteousness.

\section{Results}

1. There were 269 students who responded the questionnaires, including men for $59.5 \%$ and women for 40.5. Most students were $20-21$ years, $33.1 \%$, followed by $22-23$ years, $23.4 \%$, studying in morning session for $57.6 \%$, followed by studying in afternoon session for 23.0, and studying in the $2^{\text {nd }}$ year for $57.6 \%$, followed by studying in the $1^{\text {st }}$ year for $29.7 \%$.

2. The overall level of Buddhist morality of Thai politicians as perceived by students in all three aspects was low with a mean of 2.12 and a standard deviation of 1.216. The aspect with highest mean was the principles of building the righteousness, followed by the principles of building the unity, and the principles of building the solutions of conflicts.

3. The test of hypothesis revealed that the gender does not affect the students' opinions towards politicians' Buddhist morality, which does not meet the defined hypothesis, while the age and educational year affect the students' opinions 
towards politicians' Buddhist morality, which meets the defined hypothesis at 0.05 .

4. The students provided their recommendations on the political problems of Thai politicians in terms of the Buddhist morality that "Politicians always think of oneself, self-centered, do not listen to the opinions of others, one's own ideas are dominant, different ideas and other aspects cause disturbance and dissatisfaction of money gained, political conflicts, and divided groups of citizens". In addition, they provided their recommendations on the development of Buddhist morality for politicians that "Listen to each other, reliance on rightness rather than pleasure, adhesion to the teachings as main practices and way of life, recognition of causes and effects, do not listen to only one side, leaders should follow Buddhist concepts, no selflessness or hurting to others, politicians should have the precepts, meditation and wisdom, should more concentrate during talking, building of love to the family, and teaching of children for the future of nation".

\section{Discussion}

1. According to the results, the overall level of Buddhist morality of Thai politicians as perceived by students was low. This may be because the students are interested in the politics by pursuing political information and news regularly via many types of media, whether television or Internet, as well as they have learned the Buddhist teachings in their courses of study, such as the subjects of Theories of Politics and Ethics: To study theories of politics and ethics proposed by famous philosophers, the relations between economic structure, society, politics, roles and behavior of social classes and various groups of people in society, power, application of power, and conflict in power and interest, including social and political analysis, social and political theories proposed by famous philosophers, and ideas on economic, social and political aspects relating to the principles of Buddhism, Politics in Buddhist Approach: The meaning, definition, scopes, contents and educational approaches, forms of basic idea on political science comparing to Buddhism's approaches including Buddhism Dhamma relating to political science, and Buddhism and Thai Ways of Life: The importance of Buddhism as Thai national religion and the important foundation of the culture, the mark of unity, the institute of the nation and the King, the resource for creation of the national identity, the instrument for problem-solving and the development of the nation, the Buddhist institutionalism, the Triple Gem, the Buddhist holy days, the principles of the religious ceremony and the Buddhist activities. The analysis of nature, forms and beliefs in the Buddhism of Thai society, temples and Thai monks, the Buddhist organization, the measurement of the Buddhist study in Thailand, the promotion and protection of Buddhism, Buddhism and problem- solving and the development of Buddhism and sufficient economy.

2. According to the results, the mean level of Buddhist morality of Thai politicians as perceived by students in terms of the principles of building the solutions of conflicts was lowest but in the low level as well. This is because the media present the information and news at all times so the political conflicts can be seen with no solutions. The students thus perceived the politics negatively. This is consistent with the research of Kittaphob Chantawowng who examined Ethical Personalities of Local Politicians Base on Machiavellianism: A Case Study of Ban Bueng District, Chon Buri Province and found that 1] local politicians in Ban Bueng District, Chon Buri Province had all four Machiavellian ethical personalities: domination by deception, awareness about others' weakness and unreliability, indifference to ethical codes of one's society, and cunning at a moderate level. 2] The personal factors, i.e. gender, age, years of service, educational level, marital status, religion, salary and occupation, did not affect Machiavellian ethical personalities, except job description and conglomeration that had a partial effect. For the personalities which perceived the weakness and unreliability of others, the local politicians with different job descriptions had different personalities.. But this is' not consistent with the research of Em-on Inthanon and found that 1] As for people's attitude toward politician's ethic, the majority of the respondents agreed that the politicians has to be economical, knowledgeable, patient, humble and grateful to their motherland. They were also to be moral, and ethical and abided by the rules and regulations. They were to be responsible for leading the nation to peace and prosperity. 2] Regarding people's attitude toward politician's responsibility, the respondents mainly viewed that the politicians had to be responsible and be involved in solving social problems. They were required to listen to people's opinion so that development can be made and the problems can be effectively addressed.

3. According to the results, the mean level of Buddhist morality of Thai politicians as perceived by students in terms of the principles of building the unity was moderate but in the low level as well. This may be because the current politicians save their own and followers' benefits rather than the benefits of the nation and public. The students thus perceived a relatively low level of ethics among politicians. Therefore, the politicians should improve themselves according to the principles of building the solutions of political conflicts. The politicians must be generous and be not revengeful, they should show friendliness and goodwill to their colleagues, associated and fellow communities member family member and how to live together, they should inform the other what is benefit: they teach or advise then with a heart of goodwill: they say only polite and respectful words to them, both in their presence and in their absence, they should establish their minds in goodwill thinking of ways to be so service to each other, looking at each other in a good light, having a pleasant and congenial attitude toward each other, they should share with each other whatever gains have been rightfully acquired seeing to it that even small things are distributed equally to all, they should maintain virtuous conduct, abide by community rules and regulations, and do not conduct themselves in ways that are objectionable or damaging to the community, and Politicians should honor each other's views ; they have reached consensus or agreed upon the main principles: they adhere to the same ideals, principles of virtue or ultimate aims. So we can see that in Saraniya-dhamma: Buddhist morality for the solution of conflict, that politicians should show friendliness and goodwill to their colleagues, associated and fellow communities member family member and how show how to live together and inform the other what is of benefit. They should teach or advise them 
with a heart of goodwill. They should say only polite and respectful words to them, both in their presence and in their absence, establish goodwill, thinking of ways to be of service to each other, looking at each other in a good light, having a pleasant and congenial attitude toward each other, share with each other whatever gains have been rightfully, acquired seeing to it that even small things are distributed equally to all, maintain virtuous conduct, gained by community rules and regulations which are related the King's speech.

4. According to the results, the mean level of Buddhist morality of Thai politicians as perceived by students in terms of the principles of building the righteousness was highest but in the low level as well. This is because the students perceived the politics with regard to the positioning and hearing of political cases of independent organizations according to the Constitution. In addition, the behaviors of politicians may cause the negative opinions of students towards politicians. Therefore, the politicians should apply the principles of building the justice according to the Buddhist morality and must be ethical. According to the Buddhist principles, the politicians must sacrifice their own benefits for the public interest. Buddhist morality for the enhancement of political righteousness is 1] Dana: sharing with the populace; he is a benefactor in that he rules or works to give, not to take; he devotes himself to administering services and providing welfare and aid for the people to ensure their well-being, convenience and safety; he renders assistance to those in distress and difficulty and supports those who have done well. Politician should provide welfare and aid for the people, 2] Sila: maintaining good conduct; he is impeccable in conduct and restrained in actions and speech; he does only good actions and upholds his honor; he sets an example for the people, commands their respect and is free from any cause for contempt. Politician should do only good actions and upholds his honor, 3] Pariccaga: working selflessly; he is capable of sacrificing personal comfort, even his own life, for the benefit of the people and the peace and stability of the country. Politician should sacrifice personal conflict even his own life for the benefit of the people, 4] Ajjava: working honestly; he is honest and upholds the truth; he is free of deceit and upright in his dealings; he is sincere and does not deceive the people. Politician should be honest and upholds the truth, 5] Maddava: deporting himself with gentleness and congeniality; his bearing is not arrogant, rude, harsh or conceited; he has nobility and dignity that are based on a polite and gentle manner, inspiring devotion and loyalty but not without awe. Politician should be nobility and dignity the are based on polite and gentle, 6] Tapa: rejecting indulgence through austerity; he destroys defilements and craving and does not allow them to control his mind; he can restrain his mind and does not allow it to become lost in sensual pleasure and debauchery; he is simple and regular in life-style, and dedicated to the fulfillment of duty. Politician should restrain his mind not to lost in sensual pleasure and debauchery, 7] Akkodha: adhering to reason, not anger; he is not given to fiery outbursts and does not make judgments or act out of anger, but has a heart of goodwill, suppressing anger; he judges and acts righteously with a mind that is subtle and calm. Politician should have a heart of goodwill suppressing anger, 8] Avihimsa: bringing tranquility through nonviolence; he does not let his power go to his head or use it to repress his subjects; he is kind; he does not find a pretext for punishing a subject out of vindictiveness and hatred. Politician should be kind not find a pretext for punishing a subject out of vindictiveness and hatred,9] Khanti: overcoming difficulties with patience; he endures a heavy work load and perseveres in the face of tiredness; no matter how difficult or depressing the work may be, he does not give in; no matter how much he is provoked or ridiculed, or with whatever harsh and abrasive words, he does not despair; he refuses to abandon a task that is rightfully done. Politician should endure a heavy work load and preserve in the face of tiredness, And 10] Avirodhana: not doing that which strays from righteousness; he does not transgress the principles of public administration that are based on the welfare, happiness and righteousness of the people and the country; he does not oppose what the people rightfully desire; he does not stand in the way of those activities which are for the common good; he establishes himself firmly in righteousness, steadfast and unwavering in the face of pleasant and unpleasant words, gain and loss, desirable and undesirable conditions; he is firmly established in righteous principles and does not deviate from or subvert them-both in judicial terms, namely [the administration of] justice, and in regulatory terms, namely [the observation of] regulations, formalities and administrative principles, including good customs and traditions. Politician should establish himself firmly in righteousness stead fast and unpleasant words gain and loss desirable and undesirable conditions.

5. According to the results, the students provided their recommendations on the guidelines to the development of Buddhist morality among Thai politicians that "politicians listen to each other, reliance on rightness rather than pleasure, adhesion to the teachings as their political practices". This is because the current Thai politicians adhere to their own principles and forget the social reality in the present time. Therefore, they must consider themselves by adjusting their political practices fundamentally based on the Buddhist morality, such as prejudice, five commandments of the Buddha for the layman, and four principles of virtuous existence. If they apply these principles seriously, the can lead the nation to the civilization. This is consistent with the concepts of the scriptures [Tripitaka] which say that in addition to sacrifice of self-interest, the politicians must also take into account the political morality, and consistent with the concepts of Panida Prayoonsiri [1998] states that a good politician should have the quality of mind or ethics as follows: 1] a good politician should aim to the sake of the common good over selfinterest and partisan which is the ethics of all men in society and should want to see social peace and prosperity. However, since the politicians are those who have more power in society and contribute to the society in bringing better or worse, they should more follow this item of ethics than common people. Aristotle said, "If the government does not take into account the public interests, such government is indeed bad", 2] a good politician should behave with morals and no dissipation according to the generally accepted standards of conduct such as no lie and sincerity in both words and deeds, 3] a good politician should be responsible and accept the engagement on their duties or orders they issue. In case of any error, they should be ready for liability and quickly take corrective action as soon as possible. If the failure causes damage, they must be 
ready to consider themselves and make way for others to replace them through the peaceful process based on the social rules, and 4] a good politician must be fair. Generally, the justice is a matter of comparison of advantage and disadvantage among the people as a result of the allocation of social resources. As the politicians have the power to allocate significant and essential resources, they must be in power with justice according to the laws, regulations and rational principles by issuing orders with no dispassion or personal preference or dislike.

\section{Recommendations}

\section{Policy recommendations}

The findings from the research and discussion provide the following policy recommendations:

1.1 Political parties should have a clear policy regarding the qualifications of selecting the applicants for members of the parliament. This includes personal background that is trusted by local people and accepted by national society.

1.2 People should assemble and help political parties select the applicants for members of the parliament by using educational institutes as a center because there are educational institutes at all levels of communities in Thailand.

1.3 Independent organizations, both public and private sectors, should have a policy in defining the qualifications of politicians as accepted by the society.

1.4 All levels of politicians participate in the Buddhist activities and learn more so that they can analyze and synthesize the teachings, which leads to the creation of Thai society.

1.5 The Committee of the National Economic and Social Development Plan should have a policy to enhance the more political participation by the people, whether for the selection of applicants, establishment of policies, and performance follow up of the members of parliament and local politicians.

\section{Recommendations for further research}

This study was only a research at small points of politics in the current situation with a high level of political conflicts. Therefore, the recommendations on the subjects for future research are as follows:

2.1 Buddhism and Thai politicians

2.2 Analysis of qualifications of Thai politicians in the viewpoint of Buddhism

2.3 Building of Thai political righteousness among political leaders

2.4 Factors affecting the political conflicts in current situation

2.5 Qualifications of politicians desired by Thai people

2.6 Development of politicians and country

\section{References}

[1] Assoc.Chaiwat Attapat. Ethics. Bangkok: Ramkhamhaeng University.2000
[2] Bumphen Soongsri . The Impact of the Dissolution of Political Parties on the Development of Thai Politics: A Case Study of the Dissolution of Political Parties After September 19, 2006.

[3] Dusit Sopitcha. Political philosophy. Bangkok:

mahachulalongkornrajavidyalaya University, 2002.

[4] Em-on Inthanon. People's Expectations of Political Government Officials' Ethics: A Case Study of Thasala Sub-district, Mueang District, Chiang Mai Province. Master of Arts, Department of Government, Graduate School : Mahamakut Buddhist University, 2011.

[5] Em-on Inthanon. People's Expectations of Political Government Officials' Ethics: A Case Study of Thasala Sub-district, Mueang District, Chiang Mai Province. Master of Arts, Department of Government, Graduate School : Mahamakut Buddhist University, 2011.

[6] Jaruayporn Thoranin. Moral, ethical, moral. 2012. <http://guru.google.co.th/guru/thread?tid= $387 \mathrm{ab} 323 \mathrm{c} 08 \mathrm{e} 448 \mathrm{e}>$

[7] Jintana Chaichomphoo. An Analytical Study of Politics and Administration according to Buddhist Philosophy, Master of Arts, Department of Buddhism and Philosophy, Graduate School : Mahamakut Buddhist University, 2011

[8] Jintana Chaichomphoo. An Analytical Study of Politics and Administration according to Buddhist Philosophy, Master of Arts, Department of Buddhism and Philosophy, Graduate School : Mahamakut Buddhist University, 2011

[9] Kittaphob Chantawowng . Ethical Personalities of Local Politicians Base on Machiavellianism : A Case Study of Ban Bueng District, Chon Buri Province. 2006.

[10] Kittaphob Chantawowng . Ethical Personalities of Local Politicians Base on Machiavellianism : A Case Study of Ban Bueng District, Chon Buri Province. 2006. 
[11] Panida Prayoonsiri. Ethics. 1998. $<$ http://www.baanjomyut.com/library/ethic s/06.html>

[12] Panida Prayoonsiri. Ethics. 1998. $<$ http://www.baanjomyut.com/library/ethic s/

[13] Phamaha Choosak Khampang. Attitude of People in Thoeng District toward Thai Politicians' Ethics. Master of Arts (Political Science). Graduate School: Chiang Mai University, 2005.

[14] Phramaha Tammarat Ariyatammo. An analytical study of political science in the Tripitaka, Nakhon Pathom: Mahamakut Buddhist University. 1999.

[15] Phramahā Tawich Tirachato ( Sriprom) . The Critical Study of the Political Philosophy in the Dīghanikāya Text, Master of Arts (Philosophy), Graduate School ahachulalongkornrajavidyalaya University. 2007.

[16] Phrathampitaka (P.A. Payuto) .A Constitution for Living. 1999. <http://thammapedia.com/dhamma/books/ payutto/006.pdf>

[17] Phrathampitaka (P.A. Payutto) (1999). Ethics for Politicians, Bangkok: Buddhadharma Foundation.

[18] Pnomsit Sonprajuk . Applied Archaeology of an Unehtical Political Conducts: Study of Reflection through Newspaper Coverage of Electoral Discourse. 2009

[19] Prasit Thunyapnogchai. The opinion of Chiang Mai University Officials Toward Politicians' Ethic. Master of Arts (Political Science). Graduate School: Chiang Mai University 1994.

[20] Siwat Bunkerd . Funding Groups and Thai Politics: A Case Study of the Abuse of Political Power to Gain Business Benefits. 2004.

[21] Somsak Niamlek. Analysis of political thoughts of Buddhadasa Bhikkhu, Ramkhamhaeng University / Bangkok. 2001.
[22] Stark, Andrew. Conflict of Interest in American Public Life. Harvard University Press, 2003.

[23] Surapon Zasen. People's Attitude to Conducts of Politician into Ethics and Accountability: Case Study of Citizen in Muang Sub - district Muang District Ubonratchathani Province, 2007.

[24] Teerapat Serirangsan. Evaluation of the work of an independent constitutional organization: Election Commission, Nonthaburi: King Prajadhipok's Institute. 2005.

[25] Thatchawut Chatbandista . The Legitimacy of Thai Political Institutions: The Comparative Study on the View Point of Middle Class and Lower Class in Bangkok Metropolitan Area . Master of Arts (Political Science) Graduate School: Chiang Mai University, 2008. 